\title{
THE INDUCTION OF DIFFERENTIALLY EXPRESSED PROTEINS OF XYLELLA FASTIDIOSA WITH CITRUS EXTRACT
}

\author{
Cláudia de M. Bellato ${ }^{1 *}$; Andréia K.M. Garcia ${ }^{1}$; Fabiana Mestrinelli' ; Siu M. Tsai ${ }^{1}$; Marcos A. Machado²; \\ Lyndel W. Meinhardt ${ }^{3}$
}

${ }^{1}$ Laboratório de Biologia Celular e Molecular, CENA, Universidade de São Paulo, Piracicaba, SP, Brasil; ${ }^{2}$ Centro Apta Citros 'Sylvio Moreira', Cordeirópolis, SP, Brasil; ${ }^{3}$ Departamento de Genética e Evolução-IB, Universidade Estadual de Campinas, Campinas, SP, Brasil.

Submitted: October 10, 2003; Returned to authors for corrections: May 27, 2004; Approved: July 27, 2004

\begin{abstract}
An in vitro system was developed to induce and identify Xylella fastidiosa proteins that were differentially expressed in the presence of callus-derived extracts from its host, the citrus cultivar Pêra. To optimize the induction, we first developed a single culture medium for the growth of both, host and bacteria. This medium, CPXPm7, which mimics the citrus xylem sap, showed that $X$. fastidios $a$ at $72 \mathrm{~h}$ post-incubation had $10^{8}$ colony forming units $\mathrm{mL}^{-1}$, while Pêra cells had the highest fresh weight content $(0.79 \mathrm{~g})$. After testing various methods of co-cultivation of the bacteria and host callus grown in this single medium, the best induction procedure was to grow $X$. fastidiosa in a solid medium amended with an extract of Pêra callus grown in CPXPm7. Analysis, by two-dimensional electrophoresis, of the $X$. fastidiosa proteins ( $120 \mu \mathrm{g}$ of total proteins) grown in the presence of Pêra callus extract revealed 414 differentially expressed protein spots when compared to the protein profile obtained in the absence of the extract. The system developed in this study improves the induction and analysis of differentially expressed proteins of X. fastidiosa, which may be involved in pathogenicity.
\end{abstract}

Key words: 2DE, callus, pathogenicity, protein, Xylella-citrus interaction

\section{INTRODUCTION}

Xylella fastidiosa (X. fastidiosa), a slow-growing, xyleminhabiting Gram-negative bacterium, is a pathogen that causes Pierce's disease of grapevine (PD), phony peach disease (PPD), leaf scorch of coffee, plum, mulberry, pear, almond, elm, sycamore, oak, maple, and variegated chlorosis (CVC) of citrus $(8,33)$. Brazil is the world's largest producer of citrus with over $70 \%$ of that production in the form of orange juice concentrate. Since sweet oranges (Citrus sinensis (L.) Osbeck) are the main source for orange juice concentrate and most cultivars are susceptible to CVC, this disease poses a major threat to the Brazilian citrus industry.

$X$. fastidiosa resides in the xylem vessels of the infected plant and the growth and metabolism of the bacteria result in host-bacterial induced adaptations, which are essential for the disease process and are key points for the investigation and understanding of the host-pathogen interaction (28-30).

In vitro methods are widely utilized to study growth characteristics and nutritional demands of pathogenic bacteria as well as host-pathogen interactions (3). Nutritional media and conditions that provide the appropriate biochemical and biophysical milieu can mimic the host and stimulate the bacteria to express adaptation or pathogenicity factors $(10,25)$. The specific needs and physiological properties of each particular bacteria-host interaction require that these media be tailored specifically to maximize the response.

Due to its fastidious nature, $X$. fastidiosa requires a complex medium for growth under axenic conditions. Different media have been developed to culture these bacteria, and most of

*Corresponding author. Mailing address: Laboratório de Biologia Celular e Molecular, CENA/USP, Caixa Postal: 96. 13400-970, Piracicaba, SP, Brasil. Tel: (+5519) 3429-4643. Fax: (+5519) 3429-4610. E-mail: bellato@ cena.usp.br 
them have complex nutrients, such as tryptone, yeast extract, soytone, hemin chloride and bovine serum albumin (BSA) (57,33). Recently, Chang and Donaldson (4) investigated the nutritional requirement of $X$. fastidiosa from grape and developed a defined growth medium composed mainly of three inorganic acids, two tricarboxylic acids and 17 amino acids. Likewise, Lemos et al. (14) developed a defined growth medium for X. fastidiosa from citrus. Based upon these studies and others, we hypothesized that it was possible to develop a medium that would induce $X$. fastidiosa from citrus to express, in vitro, proteins involved in host pathogenicity. Ideally, this could be done with citrus xylem sap. However, due to the presence of endophytes in the citrus xylem sap (1) and a requirement of relatively large amounts of protein for analysis, the use of sap for in vivo studies is limited. To alleviate these problems, citrus and bacteria cells could be cultured axenically, separately or together, to conduct the interaction studies. However, the media used to culture citrus cells in vitro, such as those based upon Murashige and Skoog salts (17), do not allow the growth of $X$. fastidiosa. Likewise, the known culture media used to grow $X$. fastidiosa do not support the growth of citrus cells in vitro.

The objective of this study was to obtain potential pathogenicity proteins from a CVC isolate of Xylella fastidiosa (9a5c) through the induction of differentially expressed bacterial proteins after being co-cultivated with the citrus cv. Pêra. For that, a single culture medium for in vitro growth of citrus and $X$. fastidiosa cells was developed and utilized to test various methods of co-cultivation of the pathogen and host cells to find a procedure that optimized the induction of differentially expressed proteins. Additionally, a protein extraction and twodimensional electrophoresis (2DE) protocols were developed to maximize and improve the analysis of these differentially expressed proteins.

\section{MATERIALS AND METHODS}

\section{A single non-defined culture medium, $\mathrm{CBXPm} 7$}

A single non-defined culture medium, CBXPm7, was developed for the growth of Citrus sinensis (L.) Osbeck cv. Pêra and Xylella fastidiosa. This medium was developed to maximize growth and to standardize the analysis of the various culture methods and was formulated from Murashige and Skoog (MS) salts, PW ingredients and the composition of citrus xylem sap $(5,6,12,13,16,17,32)$. This medium was made up of a mixture of two solutions, one autoclaved (A) and the other filtered sterilized (B). The medium composition is listed below and gives the final concentration for each component in the complete medium.

Part A. $4 \mathrm{~g} \mathrm{~L}^{-1}$ Phytone peptone (BBL); $1 \mathrm{~g} \mathrm{~L}^{-1}$ Trypticase peptone (BBL); $0.002 \mathrm{~g} \mathrm{~L}^{-1}$ Hemin Chloride (Sigma); $20 \mathrm{~mL} \mathrm{~L}^{-1}$ glycerol (Sigma); $3 \mathrm{~g} \mathrm{~L}^{-1}$ PVP40 (Calbiochem); $0.125 \mathrm{mM} \mathrm{KH}_{2} \mathrm{PO}_{4}$
(Merck); $2.1 \mathrm{mMNH}_{4} \mathrm{NO}_{3}$ (Merck); $0.3 \mathrm{mM} \mathrm{CaCl}_{2} .2 \mathrm{H}_{2} \mathrm{O}$ (Merck); $0.02 \mathrm{mM} \mathrm{Na}_{2}$ FeEDTA (Merck); $0.15 \mathrm{mM} \mathrm{MgSO}_{4} .7 \mathrm{H}_{2} \mathrm{O}$ (Merck); $550 \mu \mathrm{M}$ myo-inositol (Sigma); $30 \mu \mathrm{M}$ thiamine (Sigma); $10 \mu \mathrm{M}$ pyridoxine (Sigma); $15 \mu \mathrm{M}$ nicotinic acid (Sigma); $0.4 \mathrm{mg} \mathrm{L}^{-1} 6-$ benzyl-aminopurine (6-BA) (Sigma); $100 \mu \mathrm{M} \mathrm{H}_{3} \mathrm{BO}_{3}$ (Merck); $100 \mu \mathrm{M} \mathrm{MnSO}_{4} .4 \mathrm{H}_{2} \mathrm{O}$ (Merck); $30 \mu \mathrm{M} \mathrm{ZnSO}_{4} .7 \mathrm{H}_{2} \mathrm{O}$ (Merck); 5 $\mu \mathrm{M}$ KI (Merck); $1 \mu \mathrm{M} \mathrm{Na} \mathrm{MoO}_{4} \cdot 2 \mathrm{H}_{2} \mathrm{O}$ (Merck); $0.1 \mu \mathrm{M}$ $\mathrm{CoCl}_{2} \cdot 6 \mathrm{H}_{2} \mathrm{O}$ (Merck); $0.1 \mu \mathrm{M} \mathrm{CuSO}_{4} \cdot 5 \mathrm{H}_{2} \mathrm{O}$ (Merck); $2 \mathrm{~g} \mathrm{~L}^{-1}$ phenol red (Merck); and $15 \mathrm{~g} \mathrm{~L}^{-1}$ agar (Merck) (agar was used only when preparing solid medium). The $\mathrm{pH}$ was adjusted to 5.9 prior to autoclaving at $121^{\circ} \mathrm{C}$ for $20 \mathrm{~min}$.

Part B. $1 \mathrm{~g} \mathrm{~L}^{-1}$ ascorbic acid; $1 \mathrm{~g} \mathrm{~L}^{-1}$ malic acid (ICN); $1 \mathrm{~g} \mathrm{~L}^{-1}$ sodium citrate; $1 \mathrm{~g} \mathrm{~L}^{-1}$ succinic acid (ICN); $2 \mathrm{~g} \mathrm{l}^{-1} \mathrm{~L}$-arginine (Merck); $4 \mathrm{~g} \mathrm{~L}^{-1} \mathrm{~L}$-aspartic acid; $2 \mathrm{~g} \mathrm{~L}^{-1} \mathrm{~L}$-asparagine (USB); $2 \mathrm{~g}$ $\mathrm{L}^{-1} \mathrm{~L}$-glutamic acid; $2 \mathrm{~g} \mathrm{~L}^{-1} \mathrm{~L}$-glutamine; $6 \mathrm{~g} \mathrm{~L}^{-1} \mathrm{~L}$-proline; $0.1 \mathrm{~g} \mathrm{~L}^{-1}$ of each (L-cysteine; L-glycine; L-isoleucine; L-leucine; L-lysine; L-methionine; L-phenylalanine; L-serine (Merck); L-threonine; L-tryptophan; L-tyrosine, and L-valine). All reagents were obtained from Sigma unless otherwise mentioned. After adjusting the $\mathrm{pH}$ to 5.9, the solution was sterilized through a $0.22 \mu \mathrm{M}$ filter (Nalgene) and added to the sterile medium (Part A). The two components were mixed and poured into disposable Petri dishes ( $90 \mathrm{~mm}$ x $150 \mathrm{~mm}$ ), or into sterile flasks. Liquid and plated media were stored for a week at $28^{\circ} \mathrm{C}$ in the dark prior to be used to ensure sterility.

\section{Culture of Citrus sinensis (L.) Osbeck cv. Pêra in liquid CBXPm7}

Citrus callus was derived from nucellar tissues from the sweet orange Pêra, a highly susceptible cultivar to X. fastidiosa 9 a5c. Cultures of Pêra callus were obtained from the 'Centro Apta Citros ‘Sylvio Moreira’, Cordeirópolis, SP, Brazil.

During the experimental period, citrus callus was maintained on solid Murashige and Skoog (MS) medium (15 $\mathrm{g} \mathrm{L}^{-1}$ agar), in Petri dishes ( $90 \times 150 \mathrm{~mm}$ ), supplemented with $0.4 \mathrm{mg} \mathrm{L}^{-1} 6-\mathrm{BA}$ at $28^{\circ} \mathrm{C}$ without illumination.

To evaluate the percentage of citrus cell growth on CBXPm7 and the period of maximum growth, $0.5 \mathrm{~g}$ of 20-day-old cells cultured on solid MS medium were grown in $12 \mathrm{~mL}$ of CBXPm7 medium in 50-mL conical-tubes and incubated at $28^{\circ} \mathrm{C}$ without illumination at $145 \mathrm{rpm}$. Ten tubes were incubated to evaluate the fresh weight of citrus cells every $24 \mathrm{~h}$ during five consecutive days without adding fresh medium or subcultivation. The experiment was done twice with two replicates each.

\section{Culture of Xylella fastidiosa in liquid CBXPm7}

The $X$. fastidiosa isolate 9a5c originally obtained from the sweet-orange cultivar Valência and used for the ONSA - FAPESP Genome Program (21) was maintained on solid modified PW medium (6). This medium, designated as PWB, differed from the original by containing $4 \mathrm{~g} \mathrm{~L}^{-1} \mathrm{~L}$-glutamine (instead of $40 \mathrm{~g} \mathrm{~L}^{-1}$ ) and $3 \mathrm{~g} \mathrm{~L}^{-1} \mathrm{BSA}$ (instead of $6 \mathrm{~g} \mathrm{~L}^{-1}$ ). 
The growth curve of $X$. fastidios $a$ in CBXPm7 was obtained by cultivating this bacterium initially in $25 \mathrm{~mL}$ of the same medium (starter culture) for 10 days at $28^{\circ} \mathrm{C}$ in the dark at 145 $\mathrm{rpm}$. After this period, $10 \mathrm{~mL}$ was added aseptically into an Erlenmeyer flask containing $60 \mathrm{~mL}$ of fresh CBXPm7, and the culture was incubated as before. Two $\mathrm{mL}$ were taken from this culture at zero time and every $24 \mathrm{~h}$ during six consecutive days to evaluate the number of colony forming units (cfu), through serial dilutions $\left(10\right.$ to $\left.10^{-6}\right)$, on solid CBXPm7. Each dilution had two replicates and the experiment was done twice. Colony forming units were counted $24 \mathrm{~h}$ after incubation at the same conditions as stated above utilizing a stereoscope at 40 to 50X magnification (Carl Zeiss/West/Germany).

\section{Induction methods used}

Different co-cultivation procedures using Pêra callus in association with $X$. fastidiosa cells were analyzed to determine, which was the most effective at inducing differentially expressed bacterial proteins. Five procedures were tested. 1) Pêra callus was cultured on solid MS medium and the cells were covered with Watman no.2 filter paper. This formed a nurse cell-type culture and the bacteria cells were grown on the surface of the filter paper. 2) Use of MilliCell culture plate inserts (Millipore) to grow bacterial and plant cells simultaneously in a liquid medium. Liquid CBXPm7 medium was used for that because it was the only medium suitable to support the growth of both organisms. 3) Bacterial cells grown surrounded by Pêra callus on solid medium. In this case, the Petri dish was aseptically divided using a stainless steel bar into three sections. The middle section of the plate had solid PWB medium where the $X$. fastidiosa cells were grown, and the two adjacent sections contained solid MS medium which supported the growth of Pêra callus. 4) Bacteria and Pêra cells (separated by dialysis tubing) co-cultivated together in liquid CBXPm7medium. CPXPm7 was used for the reasons stated above. 5) Bacterial cells grown on solid PWB medium amended with an extract derived from Pêra callus (Pc extract - see description below).

\section{Induction studies of $X$. fastidiosa grown on solid PWB amended with Pêra callus extracts}

Forty-three g of Pêra callus grown in $70 \mathrm{~mL}$ of CBXPm7 $(60 \% \mathrm{w} / \mathrm{v})$ for 3 days was macerated in a mortar and pestle. Afterwards, Pêra cells were disrupted mechanically in the $\mathrm{BioNeb}^{\circledR}$ Cell Disruption apparatus (Glas-Col, Terre Haute, IN, USA) under the pressure of $8 \mathrm{kgf} \mathrm{cm}^{-2}$ with nitrogen gas at a flow-rate of 17.0 liters $\mathrm{min}^{-1}$. The homogenate was centrifuged at $4,000 \mathrm{x} \mathrm{g}$ for $5 \mathrm{~min}$ at $20^{\circ} \mathrm{C}$ and the supernatant was serially filtered through Whatman paper no. 42 followed by 0.65 and $0.44 \mu \mathrm{m}$ membrane filters and finally through a $0.22 \mu \mathrm{m}$ sterile filter. An aliquot of $36 \mathrm{~mL}$ of the Pêra callus extract designated "Pc extract" was added aseptically in $300 \mathrm{~mL}$ of PWB amended with agar (at approximately $42-45^{\circ} \mathrm{C}$ ). This medium, designated as "Induced", was poured into disposable Petri dishes and allowed to solidify. Plates containing PWB medium supplemented with $36 \mathrm{~mL}$ of CBXPm7 without citrus extract were designated as "Control". Xylella 9a5c cultured on solid PWB medium was used to streak the Induced as well as the Control media. Plates were incubated at $28^{\circ} \mathrm{C} / \mathrm{dark}$, and bacterial cells were harvested from five plates for total protein extraction at various times. These induction studies were repeated at least three times. Five plates containing the PWB induced medium (without bacterial cells) were left for a week at $28^{\circ} \mathrm{C} /$ dark to monitor for any possible contamination.

\section{Extraction of whole cell proteins from $X$. fastidiosa}

Bacteria cells were collected from the surface of the plates and washed three times with $2 \mathrm{~mL}$ of Washing Buffer $(10 \mathrm{mM}$ Tris- $\mathrm{HCl} \mathrm{pH} \mathrm{8.8,} 3.0 \mathrm{mM} \mathrm{KCl}$ and $50.0 \mathrm{mM} \mathrm{NaCl}$ ) with a centrifugation for $10 \mathrm{~min}$ at $12,000 \mathrm{xg}$ at room temperature (RT) for each wash. Afterwards, cells were resuspended in $1 \mathrm{~mL}$ of Extraction Buffer [50.0 mM Tris- $\mathrm{HCl} \mathrm{pH} \mathrm{8.8,} 1.5 \mathrm{mM} \mathrm{MgCl}_{2}, 1.0$ mM EDTA pH 8.0, $10.0 \mathrm{mM} \mathrm{KCl}, 10 \mathrm{mM}$ DTT, $1.0 \mathrm{mM}$ AEBSF (Calbiochem), and $\left.1 \mathrm{~g} \mathrm{~L}^{-1} \mathrm{SDS}\right]$ and disrupted in the BioNeb ${ }^{\circledR}$ Cell Disruption System twice under a pressure of $8 \mathrm{kgf} \mathrm{cm}^{-2}$ with nitrogen gas at a flow rate of 17.0 liters $\mathrm{min}^{-1}$. Subsequently, the homogenate was centrifuged for $2 \mathrm{~min}$ at $8,000 \mathrm{xg}$ at $4^{\circ} \mathrm{C}$.

The protein concentration was determined with a commercial protein assay kit from BioRad. The solubilized proteins were stored at $-80^{\circ} \mathrm{C}$ or when necessary, lyophilized (LabConco Freeze Dryer 8, Kansas City, Missouri, USA) and stored at $20^{\circ} \mathrm{C}$ prior to $2 \mathrm{DE}$ analysis. A total amount of $120 \mu \mathrm{g}$ of protein from both, the induced and control samples, collected at various times, was analyzed through 2DE.

\section{Electrophoresis}

Isoelectric focusing (IEF) was conducted with $18 \mathrm{~cm} \mathrm{IPG}$ Immobiline DryStrips pH3-10 NL (non-linear) and pH4.5-5.5 (Amersham Biosciences). Strips were rehydrated with $400 \mu \mathrm{L}$ of IEF solution (9 M Urea; 6\% CHAPS; 70 mM DTT; $0.8 \%$ IPGbuffer; $0.006 \%$ bromophenol blue) containing the soluble $X$. fastidiosa total cell proteins $(120 \mu \mathrm{g})$ for $8-10 \mathrm{~h}$. The IEF was done with the IPGphor system (Amersham Biosciences) at 50 $\mu \mathrm{A} /$ strip until focusing reached $60-70 \mathrm{kVh}(30 \mathrm{~V} / 6 \mathrm{~h} ; 150 \mathrm{~V} / 1 \mathrm{~h}$; $350 \mathrm{~V} / 1 \mathrm{~h} ; 500 \mathrm{~V} / 1 \mathrm{~h} ; 1000 \mathrm{~V} / 1 \mathrm{~h} ; 3000 \mathrm{~V} / 1 \mathrm{~h}$, and $5000 \mathrm{~V}$ until the desired focusing time was reached). After electrophoresis, the strips were equilibrated with $50 \mathrm{mM}$ Tris- $\mathrm{HCl} \mathrm{pH} 8.4 ; 6 \mathrm{M}$ urea, $300 \mathrm{~mL} \mathrm{~L}^{-1}$ glycerol; $20 \mathrm{~g} \mathrm{~L}^{-1} \mathrm{SDS}$, and $20 \mathrm{~g} \mathrm{~L}^{-1}$ DTT at RT for 12 min. Subsequently, the strips were equilibrated with the same solution except that DTT was replaced with $30 \mathrm{~g} \mathrm{~L}^{-1}$ iodoacetamide and a trace amount of bromophenol blue at RT for $10 \mathrm{~min}$. Strips were then sealed with $1 \mathrm{~g} \mathrm{~L}^{-1}$ agarose into the top $1.5 \mathrm{~mm}$ of a $20 \times 20 \mathrm{~cm}$ vertical system (BioRad) 8-18\% gradient polyacrylamide gel. A molecular mass BenchMark ${ }^{\mathrm{TM}}$ Protein Ladder (Gibco-BRL) was used as a standard. PAGE was 
performed in the presence of the running buffer $(25 \mathrm{mM}$ Tris$\mathrm{HCl}, 192 \mathrm{mM}$ Glycine and $1 \mathrm{~g} \mathrm{~L}^{-1} \mathrm{SDS}$ ) at a constant $30 \mathrm{~mA} / \mathrm{gel}$ at $10^{\circ} \mathrm{C}$ for $5 \mathrm{~h}$ or until the bromophenol blue dye reached the bottom of the gels. The gels were rinsed three times with MilliQ water (Millipore System) for 5 min each and fixed overnight in $400 \mathrm{~mL} \mathrm{~L}^{-1}$ methanol and $100 \mathrm{~mL} \mathrm{~L}^{-1}$ acetic acid. Subsequently, they were silver-stained according to Blum et al. (2). 2DE analysis was repeated at least twice with each different protein extraction sample from the induction studies.

\section{Imaging Analysis}

After staining, 2DE gels were digitally documented with the Fluor-S MultiImager (BioRad) and analyzed with the Melanie program version 3 (Genebio, Genebra, SW). Spot intensities (as spot volume), i.e., the integrated optical density of the spot within its boundaries, were normalized as a percentage of the total spot volume, and used to quantify the protein spots from gels ran and processed in parallel from the same sample. Proteins were considered differentially expressed, up- or down-regulated, when the mean percentage of the spot volume for a particular protein varied by 1.5 -fold or greater when compared to the same protein from the control gel (31).

\section{RESULTS AND DISCUSSION}

Studies have shown that interactive growth systems where microorganisms and plant callus tissue are grown together can be used to elicit responses from the host or microorganism $(3,18,22,26)$. In an attempt to create an environment for the induction of potential Xylella fastidiosa pathogenicity genes, a single culture medium that closely mimics the components of citrus xylem was developed for the growth of citrus callus and bacteria. CBXPm7 had a mixture of ingredients that favored the growth of both $X$. fastidiosa and Pêra. This m edium had a high content of amino acids, such as arginine, aspartic acid, asparagine, glutamic acid, glutamine and proline, which have been found in sweet orange xylem sap analysis $(13,16)$. Moreover, CBXPm7 contained elevated levels of organic acids such as ascorbic acid, malic acid, citric acid (in the form of sodium citrate) and succinic acid, which were also found in xylem sap (32). The individual growth of $X$. fastidiosa and Pêra cells in CBXPm7 was assessed to determine the period of maximum growth rate of both organisms and these data were used for the induction of $X$. fastidiosa proteins by Pc extracts.

\section{Growth rate of $X$. fastidiosa in CBXPm7}

The growth of $X$. fastidiosa in CBXPm7 is given by the number of colony forming units for six consecutive days within the conditions assessed (Fig. 1A). The number of colonies per plate was recorded from the $10^{-5}$ dilution. Colonies were distinct, smooth, opalescent, and circular. At zero time, the bacterial culture had $10^{5} \mathrm{cfu} \mathrm{mL}^{-1}$, placing it at the beginning of the exponential phase. This extended up to $72 \mathrm{~h}$ followed by the stationary phase with $10^{8} \mathrm{cfu} \mathrm{mL}^{-1}$, which remained constant up to $120 \mathrm{~h}$ and afterwards dropped to $10^{7} \mathrm{cfu} \mathrm{mL}^{-1}$ during the death phase (after $120 \mathrm{~h}$ ). The coefficient for the adjustment of the data $\left(\mathrm{R}^{2}\right)$ was 0.9702 . Results showed that CBXPm7, which is rich in amino acids and organic acids, favored a faster growth of $X$. fastidiosa when compared to the data collected by Wells et al. (33), and Lemos et al. (14). Wells et al. (33) showed that different isolates of $X$. fastidiosa grown in the PW medium reached $10^{8} \mathrm{cfu} \mathrm{mL}^{-1}$ at 7 to 14 days after inoculation (stationaryphase). Lemos et al. (14) testing different culture media observed that the highest growth rate of $X$. fastidiosa (as $\mu$ g protein $\mathrm{mL}^{-1}$ ) occurred at 12 days post-inoculation. While the importance of amino acids and organic acids for Xylella growth

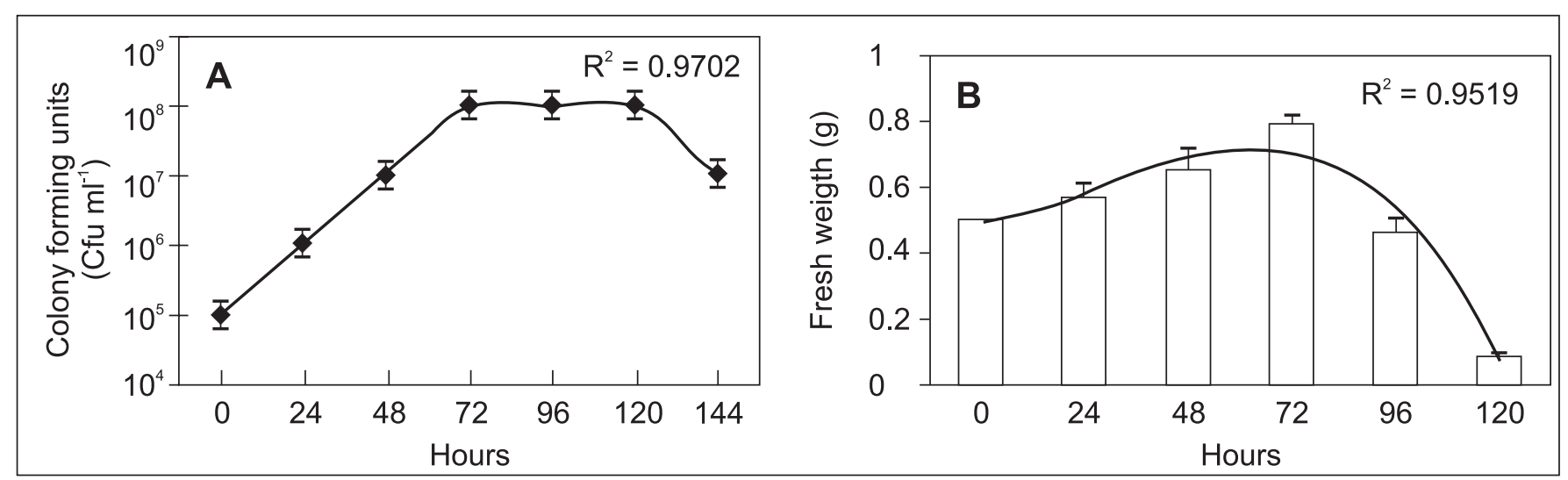

Figure 1. (A) Number of colony forming units of Xylella fastidiosa 9a5c grown on solid CBXPm7 for 6 days at 28² $/$ dark. (B) Growth of sweet orange cultivar Pêra cell suspension in liquid CBXPm7. Values represent the mean and standard deviation of two replicates from two independent experiments. 
has been reported in the literature $(5,19)$, Wells et al. (33) reported that the growth of $X$. fastidios $a$ was stimulated in the presence of amino acids in an isolate depending manner. Furthermore, CBXPm7 contains hemin chloride, which is also known to enhance the growth of $X$. fastidiosa (7). Therefore, based on the accelerated growth, the medium $\mathrm{CBXPm} 7$ apparently met the nutritional requirements of the $X$. fastidiosa isolate 9a5c.

\section{Growth rate of Pêra callus in CBXPm7}

Pêra cells were grown in liquid CBXPm7 medium for $120 \mathrm{~h}$ without adding fresh medium or subcultivation. Fig. 1B illustrates the fresh weight $(\mathrm{g})$ of Pêra cells, which during the first $72 \mathrm{~h}$ varied from 0.5 to $0.79 \mathrm{~g}$. Afterwards, the fresh weight of the culture decreased to 0.465 at $96 \mathrm{~h}$ and to 0.065 at $120 \mathrm{~h}$ postincubation. The coefficient for the adjustment of the data $\left(\mathrm{R}^{2}\right)$ was 0.9519 . To ensure that only metabolically active citrus cells were utilized for the extraction of exudates, cells were collected at $72 \mathrm{~h}$ post-inoculation to obtain Pc extracts because during the growth, plant cells synthesize and release metabolites, which can modify the general physical and physiological properties of the medium. Growing cell suspension is very complex since the medium ingredients can be converted into growth factors that promote plant cell division and growth (9). The rapid early growth rate of Pêra cells found in this study was expected due to the presence of a high content of nitrogenous compounds (amino acids, phytone peptone, trypticase peptone and organic acids), which are known to promote and increase cell growth $(9,20,27)$. Furthermore, the relatively short culture period assessed $(120 \mathrm{~h})$ showed the occurrence of Pêra cell death, which was probably followed by cell lysis as indicated at 96 and $120 \mathrm{~h}$. This observation may be the consequence of the accumulation of toxic extracellular products such as proteases, cell fragments or secondary metabolites, and nutrient limitations in the culture medium since subcultivation or addition of fresh medium was not conducted. These findings were also observed by Eriksson (9), who evaluated the growth rate of Haplopappus gracilis in 25-mL-cell suspension and by Steward et al. (24), who assessed the cell growth rate of Medicago sativa cultivated in a bioreactor. The overall pattern of the growth rate of Pêra cell grown in liquid CBXPm7 corroborates with Steward et al. (24), who found the highest growth rate of $M$. sativa in a bioreactor occurred on the third day, which was followed by the occurrence of cell death and lysis.

\section{Effect of Pc extract on the expression of Xylella fastidiosa proteins}

Preliminary results showed that procedures 1 through 4 (see Materials and Methods, Induction methods used) either did not produce enough protein to conduct the 2DE analysis; caused poor growth of bacterial cells; yielded total bacterial proteins that were contaminated with plant proteins, or produced bacterial proteins lacking any response to the presence of $\mathrm{Pc}$ extract. Only strategy 5, in which Xylella $9 \mathrm{a} 5 \mathrm{c}$ was cultivated in solid PWB supplemented with Pc extract produced from Pêra callus cultivated in liquid CBXPm7, resulted in the most effective and reproducible yields of induced bacterial proteins.

Based upon our studies, we found that a $60 \%(\mathrm{w} / \mathrm{v})$ extract (Pc extract) from Pêra cells added to solid PWB was able to stimulate the induction of differentially expressed proteins of $X$. fastidiosa. PWB medium amended with the Pc extract produced faster growth and a higher yield of proteins than the CBXPm7 solid medium amended with Pc extract (data not shown). Conversely, extract derived from citrus cells grown in MS and amended to either PWB or CBXPm7 media inhibited the growth of $X$. fastidiosa (data not shown), which could be due to the high salt content of MS, and thus, confirmed the need of a growth medium that supported the growth of both organisms. The effect of Pc extracts over time on the expression of $X$. fastidiosa proteins grown on solid PWB and analyzed via 2DE (8-18\% PAGE) (120 mg of total proteins resolved by IEF pH $3-10 \mathrm{NL}$ ) is illustrated in Fig. 2A, which shows the highest number of total proteins was on the sixth day in culture. Fig. 2B illustrates representative gels with protein spots between $\mathrm{pH} 3.5$ to 9.5 and molecular weight from 8 to $100 \mathrm{kDa}(1-, 6-$, and 10-day-old cultures). Fig. 3 shows gels with the same protein samples resolved at an IEF pH 4.5-5.5 to illustrate some of the novel, upand down-regulated proteins. Over the total analyzed period (1 to 14 days), 414 differentially expressed proteins were found, of which 180 were new, 154 were up-, and 80 were down-regulated. Within the tested conditions, only 227 protein spots were well defined and could be easily cut from the gel for future identification. Furthermore, the 2DE analysis of the Pc extract revealed no protein spots in common with those from the bacteria, confirming that no citrus proteins were carried-over during the extraction procedure (data not shown).

Over the development of this study, the extraction and 2DE protocols were optimized to take advantage of changes that have been shown to improve the quality and quantity of the $X$. fastidiosa proteins. The protocols listed in the Materials and Methods represent the most current improvements. Moreover, the 2DE protein gradient separation system used to analyze proteins obtained from bacterial cultures over time revealed that the Pc extract affected the expression of $414 \mathrm{X}$. fastidiosa proteins. Plant cells in suspension are known to be a source of biologically active factors (23). Cells in culture have advantages over whole plants due to their consistent nature, which results in a uniform well-synchronized response with the production of, for example, secondary metabolites. These metabolites may play a role in the interaction of plants with biotic and abiotic environmental factors (23). Other studies that supplemented bacterial culture media with plant leaf extract or plant flavonoids have shown that compounds derived from plant can stimulate differential expression of bacterial proteins $(11,15)$. 


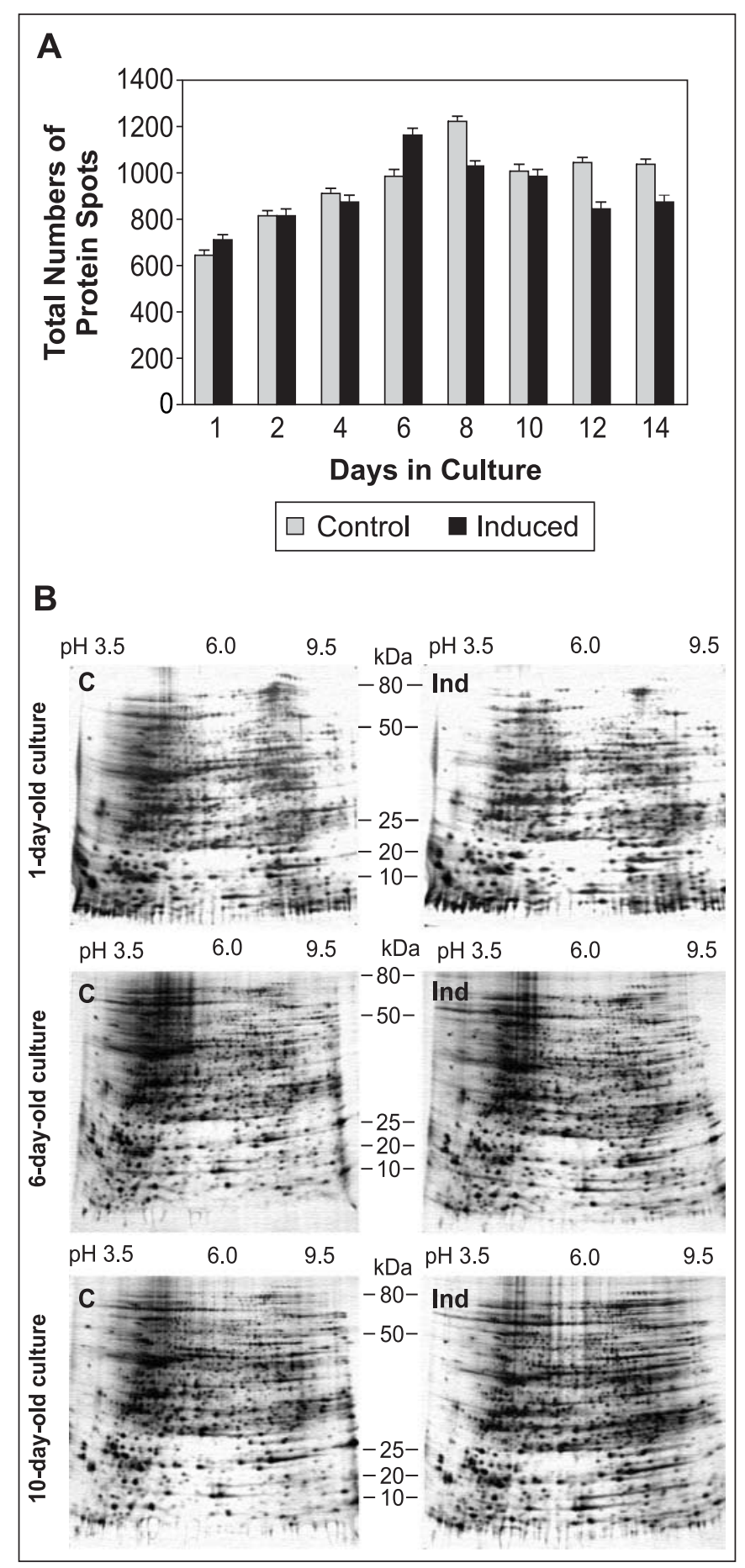

Figure 2. (A) The total number of protein spots obtained, over time, from $X$. fastidiosa 9a5c grown on solid PWB amended with Pc extract (Induced) and on solid PWB without Pc extract (Control). Total bacterial protein $(120 \mu \mathrm{g})$ was analyzed via $2 \mathrm{DE}$ (IEF pH3-10NL and 8-18\% PAGE). Values are the mean of two replicates from two independent experiments. (B) Representative gels with bacterial protein between $\mathrm{pH} 3.5$ to 9.5 and 8 to $100 \mathrm{kDa}$.
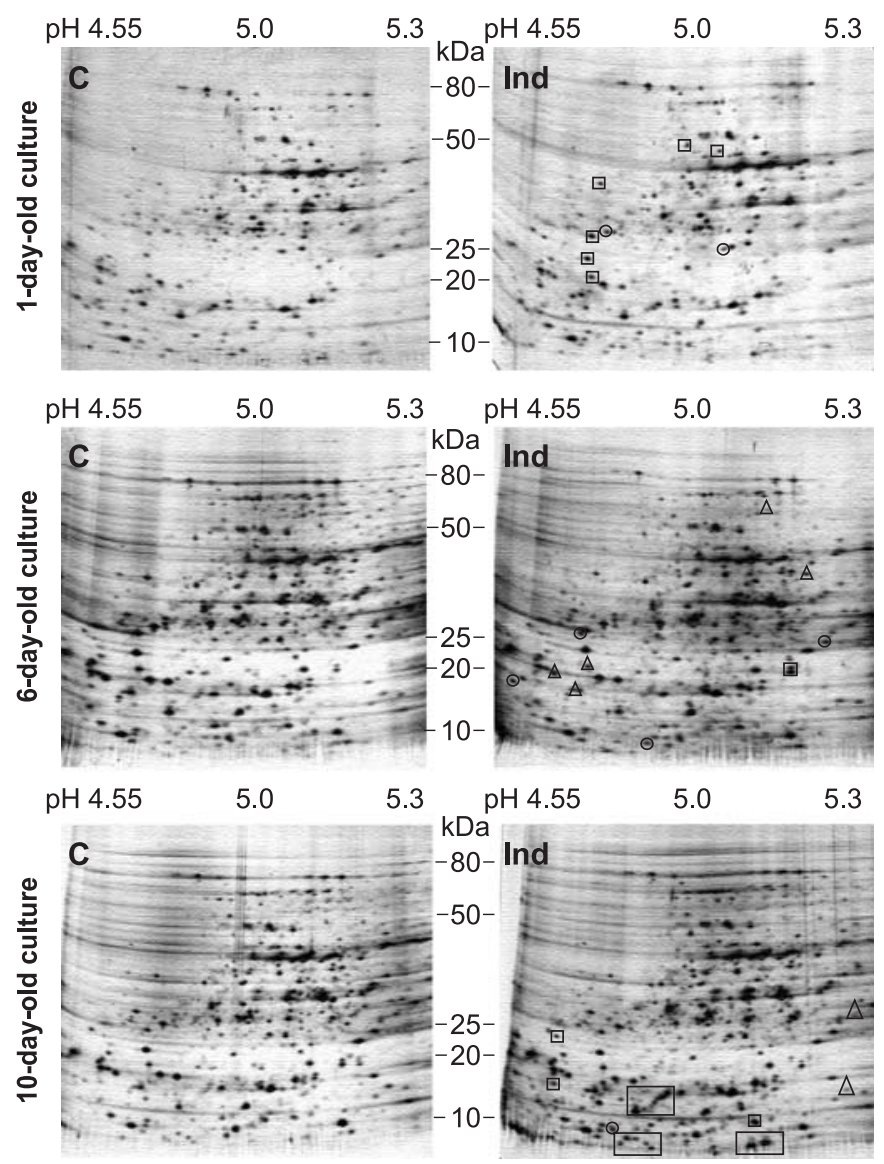

Figure 3. 2DE (IEF pH4.5-5.5 and 8-18\% PAGE) analysis of $X$. fastidiosa $9 \mathrm{a} 5 \mathrm{c}$ proteins $(120 \mu \mathrm{g})$. (Induced) is in the presence and (Control) is in the absence of Pc extract. Circles are novel; squares are up-, and triangles are down-regulated proteins when compared to the control gels.

The protocols used in this study for the protein extraction and 2DE analyses as well as the culture medium developed for the induction of $X$. fastidios a proteins showed promising results and the 227 protein spots will be processed for Maldi-TOF analysis. This in vitro study could shed additional light on the disease process of citrus variegated chlorosis (CVC) by analyzing the expression, function, and mechanism of induction/ repression as well as the synthesis of de novo proteins of Xylella genes when in the presence of metabolites derived from the host cells.

\section{ACKNOWLEDGEMENTS}

We thank "Fundação de Amparo a Pesquisa do Estado de São Paulo (FAPESP)" for the support given to this study through the Research Project and Fellowships 99/00395-6, 99/ 
07185-7, 00/07008-7, and 02/07721-0, respectively. The authors also thank Clovis A. de Souza and João G. Brancalion for their help in preparing the Figures, and Ricardo A. de Azevedo for critically reviewing the manuscript.

\section{RESUMO}

\section{Indução de proteínas de Xylella fastidiosa expressas diferencialmente com extrato de citros}

Estudos in vitro foram desenvolvidos para obter proteínas de Xylella fastidiosa expressas diferencialmente na presença de calos do hospedeiro, citros cultivar Pêra. Para otimizar a indução, desenvolveu-se um meio de cultura comum, o qual foi baseado na seiva do xilema de citros, para cultivar a bacteria e os calos de Pêra. Dados mostraram, após 72 h de cultivo neste meio, $10^{8}$ unidades formadoras de colônias de $X$. fastidiosa por $\mathrm{mL}$, e $0,79 \mathrm{~g}$ de peso seco de células de Pêra. Após testar diferentes métodos de co-cultivo da bactéria com calos de Pêra neste meio, observou-se que a melhor taxa de indução ocorreu quando $X$. fastidiosa foi cultivada em meio sólido enriquecido com um extrato derivado dos calos de Pêra. Análise em gel bidimensional (2DE) de X. fastidiosa $(120 \mu \mathrm{g})$ cultivadas na presença do extrato revelou 414 proteínas expressas diferencialmente quando comparado com o perfil proteico obtido na ausência do extrato.

Palavras-chave: calos, interação Xylella-hospedeiro, 2DE, patogenicidade, proteína

\section{REFERENCES}

1. Araújo, W.L.; Marcon, J.; Maccheroni Jr., W.; van Elsas, J.D.; van Vuurde, J.W.L.; Azevedo, J.L. Diversity of endophytic bacterial populations and their interaction with Xylella fastidiosa in citrus plants. Appl. Environ. Microbiol. 68:4906-4914, 2002.

2. Blum, H.; Beier, H.; Gross, H.J. Improved silver staining of plantproteins, RNA and DNA in polyacrylamide gel. Electrophoresis 8:9399, 1987.

3. Callahan, F.E.; Rowe, D.E. Use of a host-pathogen interaction system to test whether oxalic acid is the sole pathogenic determinant in the exudates of Sclerotinia trifoliorum. Phytopathology. 81:1546-1550, 1991.

4. Chang, C.J.; Donaldson, R.C. Nutritional requirements of Xylella fastidiosa, which causes Pierce's disease in grapes. Can. J. Microbiol. 46:291-293, 2000.

5. Chang ,C.J.; Donaldson, R.C. Xylella fastidiosa: cultivation in chemically defined medium. Phytopathology. 83:192-194, 1993.

6. Davis, M.J.; French, W.J.; Schaad, N.W. Axenic culture of the bacteria associated with phony disease of peach and plum leaf scald. Curr. Microbiol. 6:309-314 1981.

7. Davis, M.J.; Purcell, A.H.; Thomson, S.V. Isolation media for the Pierce's disease bacterium. Phytopathology. 70:425-429, 1980.

8. de Lima, J.E.O.; Miranda, V.S.; Hartung, J.S.; Brlansky, R.H.; Coutinho, A.; Roberto, S.R.; Carlos, E.F. Coffee leaf scorch bacterium: axenic culture, pathogenicity, and comparison with Xylella fastidiosa of citrus. Plant Dis. 82:94-97, 1998.
9. Eriksson, T. Studies on the growth requirements and growth measurements of cell cultures of Haplopappus gracilis. Physiol. Plant. 18:976-993, 1965.

10. Foster, J.W. Low $\mathrm{pH}$ adaptation and the acid tolerance response of Salmonella typhimurium. Crit. Rev. Microbiol. 21:215-237, 1995.

11. Guerreiro, N.; Redmond, J.W.; Rolfe, B.G.; Djordjevic, M.A. New Rhizobium leguminosarum flavonoid-induced proteins revealed by proteome analysis of differentially displayed proteins. Mol Plant Microbe Interact. 10:506-516, 1997.

12. Kao, K.N.; Michayluk, M.R. Nutritional requirements for growth of Vicia hajastana cells and protoplasts at a very low population density in liquid media. Planta. 126:105-110, 1975.

13. Kato, T. Major nitrogen compounds transported in xylem vessels from roots to top in Citrus trees. Physiol. Plant. 52:275-279, 1981

14. Lemos, E.G.M.; Alves, L.M.C.; Campanharo, J.C. Genomic-based design of defined growth media for the plant pathogen Xylella fastidiosa. FEMS Microbiol. Lett. 219:39-45, 2003.

15. Mehta, A.; Rosato, Y.B. Differentially expressed proteins in the interaction of Xanthomonas_axonopodis pv. citri with leaf extract of the host plant. Proteomics. 1:1111-1118, 2001.

16. Moreno, J.; García-Martinez, J.L. Seasonal variation of nitrogenous compounds in the xylem sap of Citrus. Physiol. Plant. 59:669-675, 1983.

17. Murashige, T.; Skoog, F. A revised medium for rapid growth and bioassays with tobacco tissue culture. Physiol. Plant. 15:473-497, 1962.

18. Nath, M.D.; Sharma, S.L.; Kant, U. Growth of Albugo candida infected mustard callus in culture. Mycopathologia 152:147-153, 2001.

19. Purcell, A.H.; Hopkins, D.L. Fastidious xylem-limited bacterial plant pathogens. Annu. Rev. Phytopathol. 34:131-151, 1996.

20. Schindler, M.; Meiners, S.; Cheresh, D.A. RGD-dependent linkage between plant cell wall and plasma membrane: consequences for growth. J. Cell Biol. 108:1955-1965, 1989.

21. Simpson, A. J. G.; Reinach, F.C.; Arruda, P.; Abreu,F. A.; Acencio, M.; Alvarenga, R; Alves, L. M. C.; Araya, J. E.; Baia, G. S.; Baptista, C. S.; Barros, M. H.; Bonaccorsi, E. D.; Bordin, S.; Bové,J. M.; Briones, M. R. S.; Bueno, M. R. P.; Camargo, A. A.; Camargo, L. E. A.; Carraro, D. M.; Carrer, H.; Colauto, N. B.; Colombo, C., Costa, F. F. Costa, M. C. R.; Costa-Neto, C. M.; Coutinho, L. L.; Cristofani, M.; Dias-Neto, E.; Docena, C.; El-Dorry, H.; Facincani, A. P.; Ferreira, A. J. S.; Ferreira, V. C. A.; Ferro, J. A.; Fraga, J. S.; França, S. C.; Franco, M. C.; Frohme, M.; Furlan, L. R.; Garnier, M. Goldman, G. H.; Goldman, M. H. S.; Gomes, S. L.; Gruber, A.; Ho, P. L.; Hoheisel, J. D.; Junqueira, M. L.; Kemper, E. L.; Kitajima, J. P.; Krieger, J. E.; Kuramae, E. E.; Laigret, F.; Lambais, M. R.; Leite, L. C. C.; Lemos, E. G. M.; Lemos, M. V. F.; Lopes, S. A.; Lopes, C. R.; Machado, J. A.; Machado, M. A.; MAdeira, A. M. B. N.; Madeira, H. M. F.; Marino, C. L.; Marques, M. V.; Martins, E. A. L.; Martins, E. M. F.; Matsukuma, A. Y.; Menck, C. F. M.; Miracca, E. C.; Miyaki1,C. Y.; MonteiroVitorello, C. B.; Moon, D. H.; Nagai, M. A.; Nascimento, A. L. T. O.; Netto, L. E. S.; Nhani Jr, A.; Nobrega, F. G.; Nunes, L. R.; Oliveira, M. A.; de Oliveira, M. C.; de Oliveiras, R. C.; Palmieri, D. A.; Paris, A.; Peixoto, B. R.; Pereira, G. A. G.; Pereira Jr, H. A.; Pesquero, J. B.; Quaggio, R. B.; Roberto, P. G.; Rodrigues, V.; de M. Rosa, A. J.; de Rosa Jr, V. E.; de Sa, R. G.; Santelli, R. V.; Sawasaki, H. E.; da Silva, A. C. R.; da Silva, A. M.; da Silva, F. R.; Silva Jr, W. A.; da Silveira, J. F.; Silvestri, M. L. Z.; Siqueira, W. J.; de Souza, A. A.; de Souza, A. P.; Terenzi, M. F.; Truffi, D.; Tsai, S. M.; Tsuhako, M. H.; Vallada, H.; Van Sluys, M. A.; Verjovski-Almeida, S.; Vettores, A. L.; Zago, M. A.; Zatz, M.; Meidanis, J.; Setubal, J. C. The genome sequence of the plant pathogen Xylella fastidiosa. Nature. 406: 151-157, 2000.

22. Souissi, T.; Kremer, R.J. Leafy spurge (Euphorbia esula) cell cultures for screening deleterious rhizobacteria. Weed Sci. 42:310-315, 1994. 
23. Stafford, A.M. Plant cell cultures as a source of bioactive small molecules. Curr. Opin. Drug\&Dev. 5:296-303, 2002.

24. Steward, N.; Martin, R.; Engasser, J.M.; Goergen, J.L. Determination of growth and lysis kinetics in plant cell suspension cultures from the measurement of esterase release. Biotechnol. Bioeng. 66:114121, 1999.

25. Svensäter, G.; Björnsson, O.; Hamilton, I.R. Effect of carbon starvation and proteolytic activity on stationary-phase acid tolerance of Streptococcus mutans. Microbiology. 147:2971-2979 2001.

26. Tomaso-Peterson, M.; Krans, J.V. Evaluation of a new in vitro cell selection technique. Crop Sci. 30:226-229, 1990.

27. Torrey J.G.; Reinert, J. Suspension cultures of higher plant cells in synthetic media. Plant Physiol. 36:483-491, 1961.

28. Vasse, J.; Genin, S.; Frey, P.; Boucher, C.; Brito, B. The hrpB and $h r p C$ regulatory genes of Ralstonia solanacearum are required for different stages of the tomato root infection process. Mol. Plant Microbe Interact. 13:259-267, 2000.
29. Vereecke, D.; Burssens, S.; Simon-Mateo, C.; Inze, D.; van Montagu, M.; Goethals, K.; Jaziri, M. The Rhodococcus fascians-plant interaction: morphological traits and biotechnological applications. Planta. 210:241-251, 2000.

30. Weinrauch, Y.; Zychlinsky, A. The induction of apoptosis by bacterial pathogens. Annu. Rev. Microbiol. 53:155-187, 1999.

31. Wilkins, J.C.; Homer, K.A.; Beighton, D. Altered protein expression of Streptococcus oralis cultured at low $\mathrm{pH}$ revealed by twodimensional gel electrophoresis. Appl. Environ. Microbiol. 67:3396$3405,2001$.

32. Wutscher, H.K.; McDonald, R.E. Mineral elements and organic acids in branch and root xylem sap of healthy and blight-affected sweet orange trees. J. Amer. Soc. Hort. Sci. 111: 426-429, 1986.

33. Wells, J.M.; Raju, B.C.; Hung, H.; Weisburg, W.G.; Mandelco-Paul, L.; Brenner, J. Xylella fastidiosa gen. nov., sp. nov: gram-negative, xylem-limited, fastidious plant bacteria related to Xanthomonas spp. Int. J. Syst. Bacteriol. 31:136-143, 1987. 